\title{
Phosphorylation represses Ets-1 DNA binding by reinforcing autoinhibition
}

\author{
Dale O. Cowley and Barbara J. Graves ${ }^{1}$ \\ Huntsman Cancer Institute, University of Utah, Salt Lake City, Utah 84112-5550 USA
}

\begin{abstract}
Phosphorylation of transcription factors is a key link between cell signaling and the control of gene expression. Here we report that phosphorylation regulates DNA binding of the Ets-1 transcription factor by reinforcing an autoinhibitory mechanism. Quantitative DNA-binding assays show that calcium-dependent phosphorylation inhibits Ets-1 DNA binding 50-fold. The four serines that mediate this inhibitory effect are distant from the DNA-binding domain but near structural elements required for autoinhibition. Mutational analyses demonstrate that an intact inhibitory module is required for phosphorylation-dependent regulation. Partial proteolysis studies indicate that phosphorylation stabilizes an inhibitory conformation. These findings provide a structural mechanism for phosphorylation-dependent inhibition of Ets-1 DNA binding and demonstrate a new function for inhibitory modules as structural mediators of negative signaling events.
\end{abstract}

[Key Words: Ets-1; phosphorylation; autoinhibition; transcription factor; DNA binding]

Received October 8, 1999; revised version accepted December 20, 1999.

Signal transduction pathways modulate gene expression through phosphorylation of regulatory transcription factors. Any of the functions performed by transcription factors, including DNA binding, transcriptional activation, transcriptional repression, subunit association, or nuclear localization, can be targets for this regulation. For example, sequence-specific DNA binding by the p53 protein is stimulated by phosphorylation of the carboxyl terminus (Ko and Prives 1996). Phosphorylation of the NFAT family of factors controls nuclear transport (Rao et al. 1997). Phosphorylation of CREB, NF-кB, and Elk-1 enhances their transcriptional activities /Gonzalez and Montminy 1989; Marais et al. 1993; Treisman 1994; Finco et al. 1997; Montminy 1997; Zhong et al. 1998). Although many examples of phosphorylation-dependent transcriptional regulation have been described, few cases are understood at the structural and mechanistic level. The regulation of Ets-1 DNA binding by phosphorylation provides an opportunity to bring structural data into a mechanistic study of post-translational regulation.

A detailed structural framework is available for studies on the regulation of Ets-1 DNA binding. The ETS domain of Ets-1 displays a winged-helix-turn-helix motif that recognizes a GGAA/T core sequence as a monomer (Nye et al. 1992; Donaldson et al. 1996; Kodandapani et al. 1996; Werner et al. 1997; Batchelor et al. 1998; Mo et al. 1998). More interestingly, an autoinhibitory mechanism regulates Ets-1 DNA binding (Hagman and Grosschedl 1992; Lim et al. 1992; Wasylyk et al. 1992; Graves et al. 1998; Fig. 1). Three $\alpha$-helices (HI-1,

${ }^{1}$ Corresponding author.

E-MAIL barbara.graves@hci.utah.edu; FAX (801) 585-1980.
$\mathrm{HI}-2$, and H4) interact with each other and $\mathrm{H} 1$ of the ETS domain to produce a metastable inhibitory module (Donaldson et al. 1996; Skalicky et al. 1996). A conformational change of the inhibitory module accompanies DNA binding. This structural transition includes unfolding of helix HI-1 that is detected as DNA-induced protease sensitivity (Petersen et al. 1995; Jonsen et al. 1996). The coupling of helix unfolding to DNA binding is thought to be the basis of Ets-1 autoinhibition. We have proposed that this DNA-induced conformational change provides a structural switch to modulate Ets-1 DNA binding (Graves et al. 1998).

A variety of regulatory strategies could use this inhibitory mechanism. It is frequently suggested that autoinhibition could be countered by positive signals to allow high-affinity DNA binding. For example, Ets-1 binds DNA cooperatively with a number of partner proteins (Graves and Petersen 1998). In the case of CBF 2 /AML1, the partner protein facilitates Ets-1 DNA binding by counteracting autoinhibition (Goetz et al. 2000; Gu et al. 2000). Phosphorylation of Ets-1 could also rescind autoinhibition. We considered whether Ras/MAP kinase signaling, which stimulates Ets-1 transcriptional activity (Yang et al. 1996), could play this role. However, MAP kinase phosphorylation of Ets-1 does not affect DNA binding (B. Colson and B.J. Graves, unpubl.), ruling out a role for this modification. On the other hand, phosphorylation of Ets-1 by calcium signaling pathways has been reported to inhibit DNA binding (Fisher et al. 1994; Rabault and Ghysdael 1994). Calcium-dependent phosphorylation targets at least four serines amino-terminal of the ETS domain near inhibitory helices HI-1 and HI-2 (Rabault and Ghysdael 1994; Fig. 1C). These observa- 

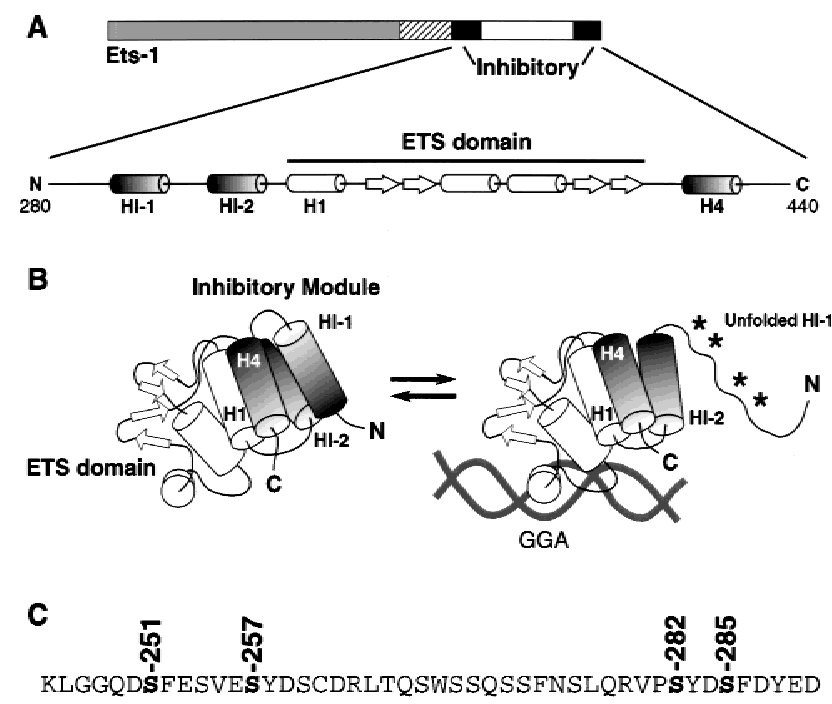

Figure 1. Model of Ets-1 autoinhibition. $(A)$ Schematic of Ets-1 showing DNA-binding domain (ETS domain, white), regions required for autoinhibition (inhibitory, black) and calcium-dependent phosphorylation (hatched). Expanded: secondary structural elements of the inhibitory module and ETS domain. $\alpha$-Helices are indicated by barrels; $\beta$ strands by arrows. $(B)$ Structural model. $\alpha$-Helices H1, HI-1, HI-2, and H4 form the inhibitory module. DNA binding is coupled to a conformational change that includes loss of structure in helix HI-1 and exposure of proteolytic cleavage sites (asterisks, Petersen et al. 1995; Jonsen et al. 1996). (C) Amino acid sequence spanning sites of calciumdependent phosphorylation (hatched in A). In vivo calcium-dependent phosphorylation sites are indicated (Rabault and Ghysdael 1994).

tions led us to hypothesize that rather than disrupting autoinhibition, calcium-dependent phosphorylation might use the structural switch to negatively regulate DNA-binding activity. This type of regulation would represent a novel use of autoinhibition in a biological setting.

In this report, we link the autoinhibitory mechanism to phosphorylation-dependent inhibition of DNA binding. We developed an in vitro system that provided a quantitative analysis of phosphorylation-dependent inhibition, establishing both the magnitude of the inhibition and the relative contributions of the multiple phosphorylation sites. Importantly, the in vitro system allowed us to test the role of the inhibitory module directly. We found that mutational disruption of the inhibitory module impairs phosphorylation-dependent repression of DNA binding. Furthermore, phosphorylation of Ets-1 enhances protease resistance within the inhibitory module. Together, these findings indicate that phosphorylation mediates its inhibitory effects via stabilization of the inhibitory module. Thus, this study demonstrates that the inhibitory module of Ets-1 facilitates regulation not only by positive signals that counteract autoinhibition but also by negative signals that reinforce autoinhibition.

\section{Results \\ In vitro analysis of calcium-dependent Ets-1 phosphorylation}

To determine the mechanism by which calcium-dependent signaling pathways regulate Ets-1 DNA binding, we developed an in vitro system suitable for quantitative and structural analysis. T-cell nuclear extract and calmodulin-dependent kinase II (CaMKII) phosphorylated bacterially expressed, purified Ets-1 on approximately six and four sites, respectively (Fig. 2A; Table 1). Approximately one to two sites were modified by nuclear extract without calcium (Fig. 2B). Together, these results indicate that four to five sites are targets of calciumdependent phosphorylation by either nuclear extract or CaMKII in vitro. In vivo studies with transiently overexpressed Ets-1 suggested that at least four sites are phosphorylated following calcium-ionophore treatment of cells (Rabault and Ghysdael 1994), demonstrating that our in vitro system is suitable for mechanistic studies.

\section{Phosphorylation inhibits Ets-1 DNA binding 50-fold}

To measure inhibitory effects of phosphorylation on Ets-1 DNA binding, we used a quantitative electrophoretic mobility shift assay (EMSA) to determine equilibrium dissociation binding constants $\left(K_{d}\right)$ of mock-treated or phosphorylated Ets-1. In the case of nuclear extract, competing binding activities in the extract interfered with the ability to accurately measure the affinity of phosphorylated Ets-1 (see Materials and Methods; Table 1). Therefore, Flag-tagged Ets-1 was treated and subsequently repurified prior to analysis of DNA binding. Phosphorylation of Ets-1 by either nuclear extract or CaMKII reduced its affinity for DNA $~ 50$-fold (Fig. 2C,D; Table 1). Alkaline phosphatase treatment of extractphosphorylated, repurified Flag-Ets-1 resulted in a 42fold increase in affinity (Fig. 2E; Table 1), demonstrating that the effect was reversible and was not a result of Ets-1 degradation in the nuclear extract. Together, these results establish that calcium-dependent phosphorylation inhibits Ets-1 DNA binding 50-fold. These quantitative analyses set the stage to investigate the mechanism of phosphorylation-dependent Ets-1 inhibition.

\section{Four phosphoserines cooperatively inhibit Ets-1 DNA binding}

We first explored the contributions of various phosphorylation sites to inhibition. A previous study identified four serines as targets of calcium-dependent phosphorylation in vivo (Rabault and Ghysdael 1994; Fig. 1C). We mutated all four serines together or in pairs to alanine and tested the phosphorylation and inhibition of these mutants. Mutation of all four serines to alanine (4S-A) reduced phosphorylation by either nuclear extract or CaMKII to a level of approximately one mole of phosphate per mole of Ets-1 (Table 1). The residual phosphorylation of this mutant had very little effect on its 

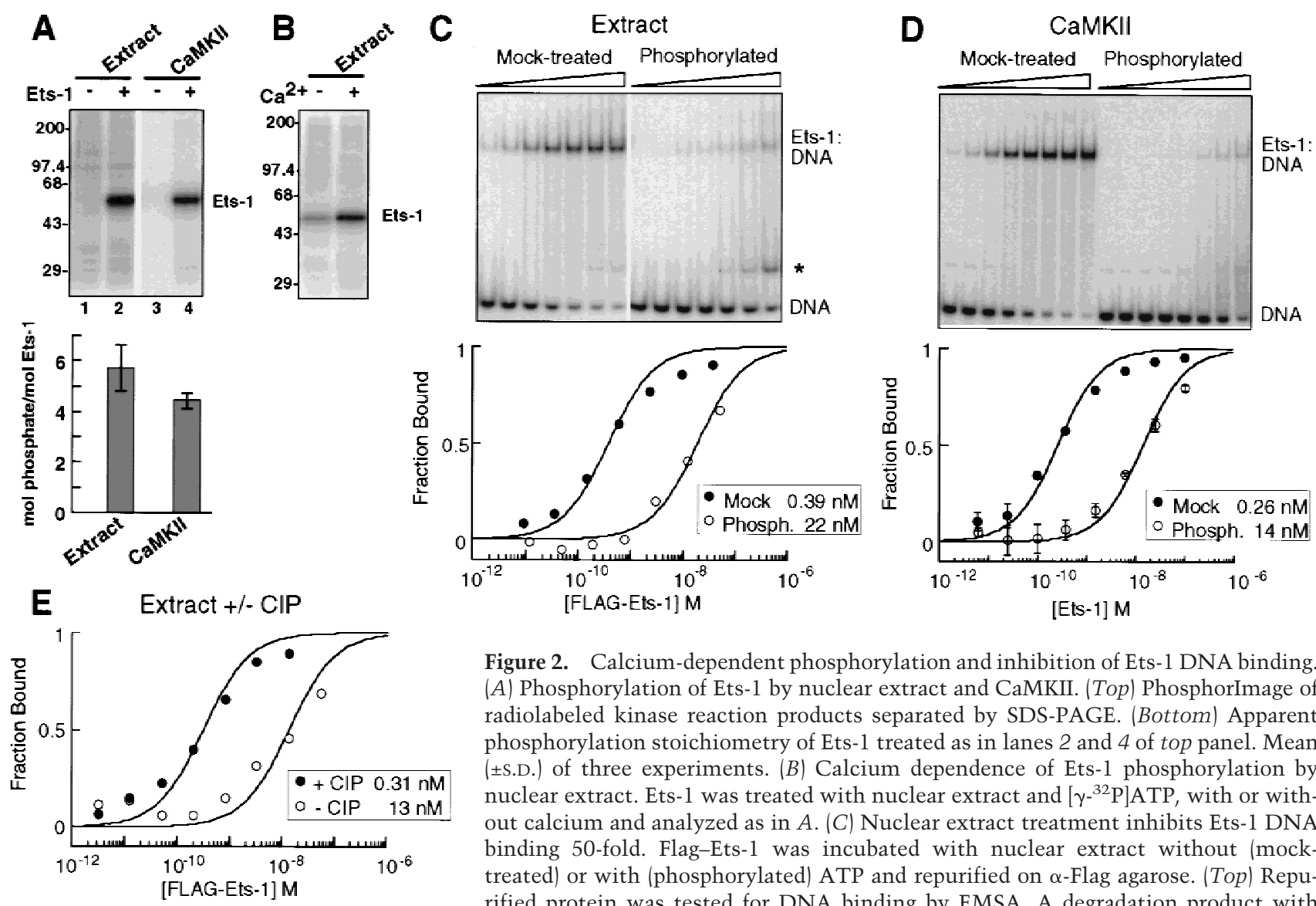

Figure 2. Calcium-dependent phosphorylation and inhibition of Ets-1 DNA binding. (A) Phosphorylation of Ets-1 by nuclear extract and CaMKII. (Top) PhosphorImage of radiolabeled kinase reaction products separated by SDS-PAGE. (Bottom) Apparent phosphorylation stoichiometry of Ets-1 treated as in lanes 2 and 4 of top panel. Mean $( \pm$ S.D.) of three experiments. (B) Calcium dependence of Ets-1 phosphorylation by nuclear extract. Ets-1 was treated with nuclear extract and $\left[\gamma_{-}{ }^{32} \mathrm{P}\right] \mathrm{ATP}$, with or without calcium and analyzed as in $A$. $(C)$ Nuclear extract treatment inhibits Ets-1 DNA binding 50-fold. Flag-Ets-1 was incubated with nuclear extract without (mocktreated) or with (phosphorylated) ATP and repurified on $\alpha$-Flag agarose. (Top) Repurified protein was tested for DNA binding by EMSA. A degradation product with DNA-binding activity is indicated $\left({ }^{*}\right)$. (Bottom) Binding curves were generated by measuring the free DNA signal. $K_{d}$ s (inset) were determined by curve-fitting to $[D P] /\left[D_{t}\right]=1 /\left(1+\left(K_{d} /[P]\right)\right)$. $(D)$ CaMKII treatment inhibits Ets-1 DNA binding 50-fold. (Top) EMSA of Ets-1 treated with CaMKII without (mock-treated) or with (phosphorylated) unlabeled ATP. Reaction products were used in DNAbinding assays without repurification. (Bottom) Binding curves were generated from mean ( \pm S.D.) of three EMSA performed as in top panel and analyzed as in C. $(E)$ Ets-1 DNA-binding inhibition is reversed by phosphatase treatment. Phosphorylated, repurified Flag-Ets-1 was mock-treated or incubated with calf intestinal phosphatase (CIP). EMSA analysis was used to derive DNA-binding curves and equilibrium dissociation binding constants as in $C$.

DNA-binding affinity (Table 1), indicating that at least one of these serines is required to mediate dramatic effects on Ets-1 DNA binding. Mutation of the serines in pairs resulted in intermediate phosphorylation levels of two to three phosphates per Ets-1 molecule by nuclear extract (S251A;S257A, S282A;S285A, Table 1). However, phosphorylation of these double mutants decreased their DNA-binding affinities only four- and sixfold, respectively (Table 1). This result suggests that the 50 -fold inhibition of wild-type Ets-1 is due to a synergistic effect of the two pairs of phosphorylated residues.

The cooperative requirement for multiple phosphoserines in inhibition suggests that structural elements might coordinate the interdependent activity of each phosphate. The phosphorylation sites are near the amino-terminal inhibitory helices (Fig. 1), suggesting that phosphorylation might inhibit DNA binding by regulating the function of the inhibitory module. Specifically, our model of autoinhibition predicts that the conformational equilibrium of the inhibitory module determines the affinity of Ets-1 for DNA. Phosphorylation could inhibit Ets-1 DNA binding by affecting this equilibrium. This model makes two principal predictions. First, the structure and function of the inhibitory module should be critical for phosphorylation-dependent inhibition. Second, an increase in the stability of the inhibitory module should be detectable following phosphorylation.

\section{Disruption of the inhibitory module blocks phosphorylation-dependent inhibition}

To determine whether the structure and function of the inhibitory module are important for phosphorylation-dependent regulation, we first generated single amino acid substitutions that disrupt Ets-1 autoinhibition. Tyrosine 307 in helix HI-1 was mutated to proline, which is expected to constitutively unfold this metastable helix (Fig. 3A, Y307P). Leucine 429 in helix H4 was mutated to alanine to disrupt packing of the inhibitory module (Fig. 3A, L429A; Jonsen 1999). The Y307P and L429A proteins displayed enhanced DNA binding relative to wild-type 
Table 1. Phosphate incorporation and phosphorylation-dependent inhibition of Ets-1 and mutants

\begin{tabular}{|c|c|c|c|}
\hline Ets-1 protein & Treatment ${ }^{\mathrm{a}}$ & $\begin{array}{c}\text { mol } \\
\text { phosphate/ } \\
\text { mol Ets-1 } \\
\text { (mean } \pm \text { S.D.) }\end{array}$ & $\begin{array}{c}\text { Fold } \\
\text { inhibition }^{\mathrm{b}} \\
\text { (mean } \pm \text { S.D.) }\end{array}$ \\
\hline Ets-1 & extract & $5.7 \pm 0.9$ & $16.6 \pm 1.3^{\mathrm{c}}$ \\
\hline Flag-Ets-1 & $\begin{array}{l}\text { extract, } \\
\text { repurified }\end{array}$ & N.D. & $62.6 \pm 8.7^{\mathrm{d}}$ \\
\hline Flag-Ets-1 & $\begin{array}{c}\text { extract }+ \text { ATP } \\
\text { repurified, } \pm \\
\text { phosphatase }\end{array}$ & N.D. & $41.9^{\mathrm{e}}$ \\
\hline Ets-1 & CaMKII & $4.4 \pm 0.3$ & $55.7 \pm 9.5$ \\
\hline $4 S-A$ & extract & $0.73 \pm 0.2$ & $1.3 \pm 0.2$ \\
\hline $4 S-A$ & CaMKII & $1.4^{\mathrm{e}}$ & $3.0^{\mathrm{d}}$ \\
\hline S251A, S257A & extract & $2.0 \pm 0.4$ & $3.7 \pm 1.6$ \\
\hline S282A, S285A & extract & $3.3 \pm 0.6$ & $5.7 \pm 1$ \\
\hline L429A & extract & $4.3 \pm 0.5$ & $2.1 \pm 0.4$ \\
\hline Flag-L429A & $\begin{array}{c}\text { extract }+ \text { ATP } \\
\text { repurified, } \pm \\
\text { phosphatase }\end{array}$ & N.D. & $6.2^{\mathrm{e}}$ \\
\hline L429A & CaMKII & $4.9 \pm 0.4$ & $5.8 \pm 2.0$ \\
\hline Y307P & extract & $4.2 \pm 2.3$ & $7.0 \pm 3.0$ \\
\hline
\end{tabular}

Values represent mean of three experiments except where noted otherwise. (N.D.) Not determined

aEts-1 proteins were treated with indicated agent \pm ATP except where noted otherwise.

${ }^{\mathrm{b}}$ Fold inhibition $=K_{d}$ phosphorylated $/ K_{d}$ mock-treated.

${ }^{c}$ Represents a minimum estimate (see Materials and Methods).

${ }^{\mathrm{d}}$ Mean of two experiments.

${ }^{\text {e}}$ Value from a single experiment.

Ets-1 (Fig. 3B), consistent with a loss of autoinhibition. Partial proteolysis was used to determine if the mutations disrupted the inhibitory module (Fig. 3C). Multiple sites within inhibitory helix HI-1 become accessible to trypsin cleavage after the unfolding of the inhibitory module (Petersen et al. 1995; Jonsen et al. 1996; Fig. 1). When compared with wild-type Ets-1, cleavage at these sites was dramatically enhanced in both the L429A and Y307P proteins as evidenced by the appearance of T5 (Fig. 3C). Other cleavage sites such as the lysine at the amino terminus of $\mathrm{T} 3$ were unaffected by the mutations, indicating that the proteins were not globally misfolded. The enhanced DNA binding and protease sensitivity of the Y307P and L429A mutants indicate that the mutations cause constitutive unfolding of HI- 1 and a loss of autoinhibition.

We analyzed phosphorylation and DNA binding of L429A and Y307P to determine the effects of inhibitory module disruption on phosphorylation-dependent inhibition. L429A and Y307P were phosphorylated by nuclear extract at levels similar to wild-type Ets-1 (Fig. 4A; Table 1). Additionally, CaMKII phosphorylated L429A to the same extent as wild-type Ets-1 (Fig. 4A; Table 1). However, L429A and Y307P were inhibited only three- to sevenfold by treatment with either nuclear extract or CaMKII (Fig. 4B-D; Table 1). The same result also was found when Flag-tagged L429A was phosphory- lated by nuclear extract, repurified, and treated with phosphatase (Table 1). These findings contrast with the 50-fold inhibition of wild-type Ets-1. The data suggest that the two mutant forms of Ets-1, although fully phosphorylated, cannot mediate the inhibitory effects of this phosphorylation because of the constitutive disruption of the inhibitory module. We conclude that a functional inhibitory module is essential for the phosphorylationdependent inhibition of Ets-1 DNA binding.
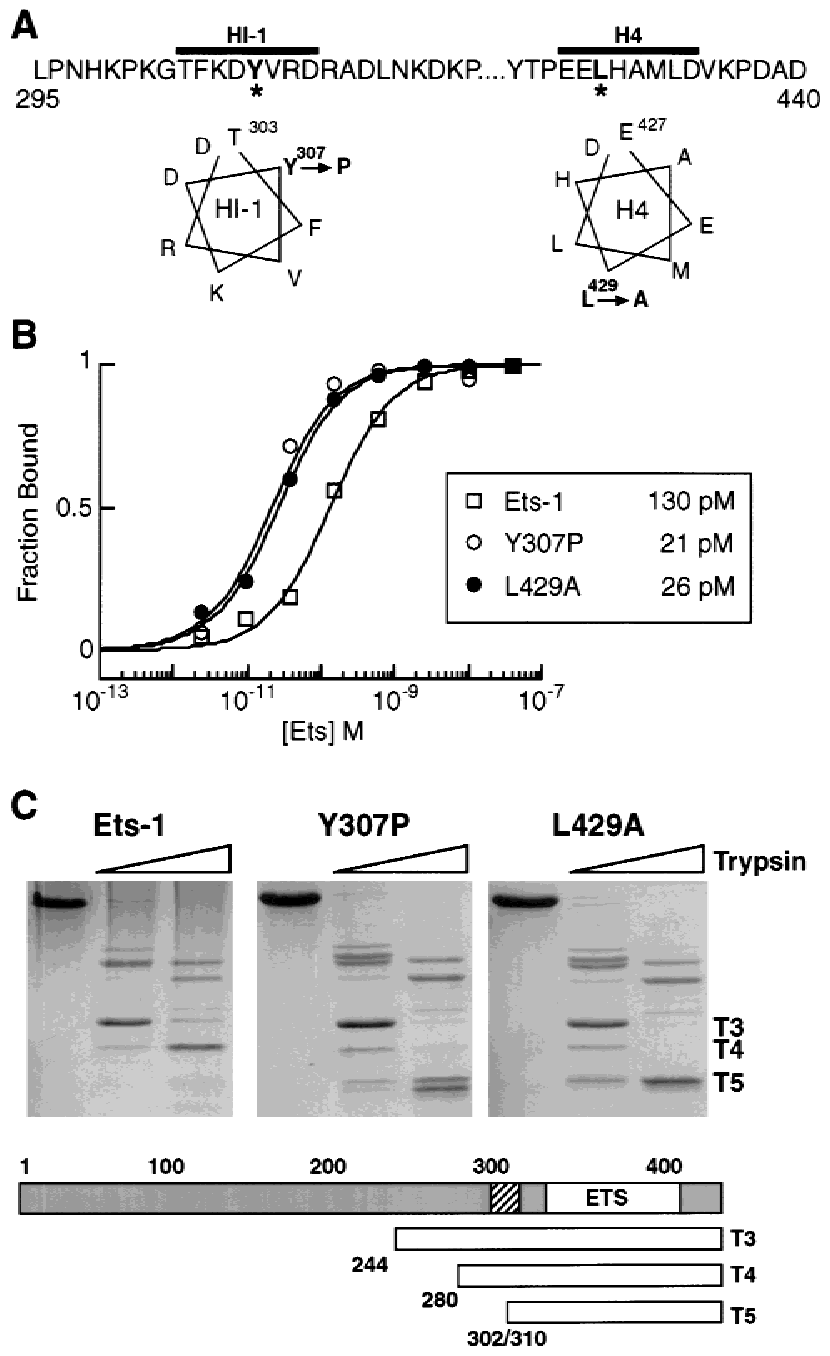

Figure 3. Mutational disruption of the Ets-1 inhibitory module. (A) Sequence and secondary structure of inhibitory helices HI-1 and H4. Y307P and L429A mutations are marked with asterisks and designated on helical wheel diagrams. (B) DNAbinding affinities of Ets-1, Y307P, and L429A. Binding curves and $K_{d}$ values (inset) were derived from EMSA of bacterially expressed, purified proteins. (C) Trypsin proteolysis of Ets-1, Y307P, and L429A. (Top) Coomassie blue-stained SDS-PAGE of protease digestion products; (bottom) cleavage positions of T3, $\mathrm{T} 4$, and $\mathrm{T} 5$ fragments are indicated relative to inhibitory helix HI-1 (hatched) and the ETS domain (ETS, white). Note that T5 represents a doublet with products cleaved at position 302 or 310. 
A
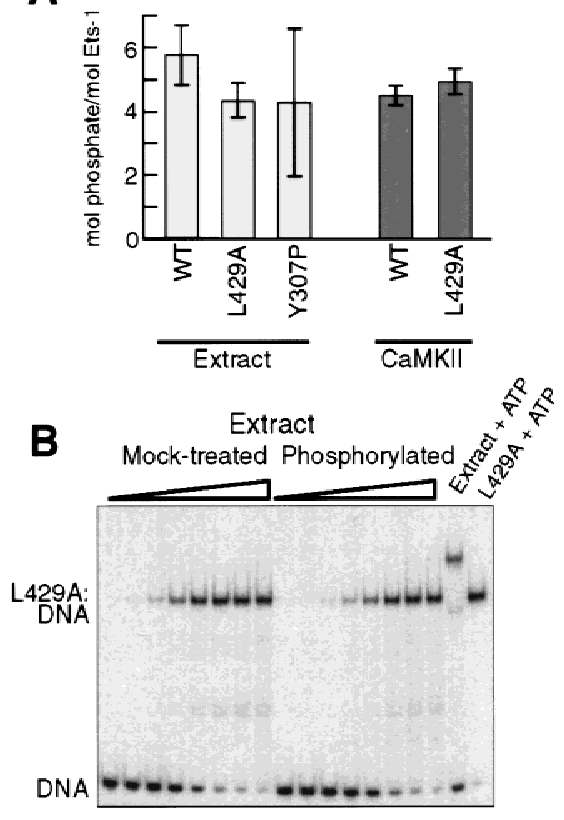

C

\begin{tabular}{|c|c|c|}
\hline \multicolumn{3}{|c|}{$\mathrm{K}_{\mathrm{D}}$ (nM) } \\
\hline & Mock-treated & Phosphorylated \\
\hline \multicolumn{3}{|c|}{ Extract } \\
\hline L429A & 0.25 & 0.50 \\
\hline Y307P & 0.10 & 0.68 \\
\hline \hline \multicolumn{3}{|c|}{ CaMKII } \\
\hline L429A & 0.13 & 0.75 \\
\hline
\end{tabular}

\section{D}

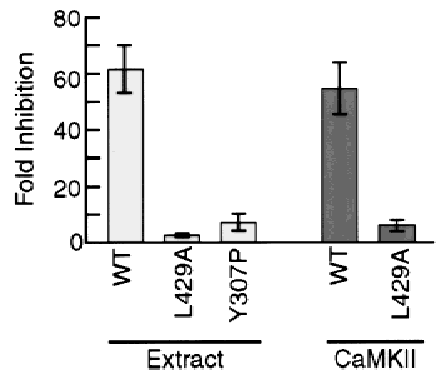

Figure 4. A disrupted inhibitory module impairs phosphorylation-dependent repression of DNA binding. $(A)$ Phosphorylation of wild-type Ets-1 and inhibitory-module mutants by nuclear extract or CaMKII. Bars indicate mean phosphate incorporation ( \pm S.D.) from three experiments. $(B)$ Equilibrium DNA-binding studies of L429A. L429A was treated with nuclear extract without (mock-treated) or with (phosphorylated) ATP. Reaction mixtures were diluted into DNA-binding buffer and analyzed by EMSA. (C) $K_{d}$ of mock-treated and phosphorylated L429A and Y307P. L429A and Flag-Y307P were treated with nuclear extract and analyzed as in $B$; L429A was treated with CaMKII and analyzed as in Fig. 2D. $K_{d}$ values were obtained from mean data points of three experiments. (D) Phosphorylation-dependent inhibition of wild-type Ets-1, L429A, and Y307P. Mean ( \pm S.D.) inhibition values were determined from $K_{d}$ values of two [extracttreated wild-type (WT)] or three (all others) individual EMSA experiments. Extract-treated wild-type represents inhibition of Flag-Ets-1 repurified from nuclear extract as in Fig. 2C.

\section{Phosphorylation stabilizes the inhibitory module}

We next sought to test the second prediction of our model, that the repressive effects of phosphorylation are due to stabilization of the inhibitory module. As presented earlier, the loss of structure of the inhibitory module can be monitored by partial trypsin proteolysis. We reasoned that protease sensitivity could also detect inhibitory module stabilization. However, trypsin was not suitable for this purpose because a major cleavage site of trypsin lies at position 280, between the two pairs of phosphoacceptor sites (Fig. 5A). To solve this problem, we chose endoproteinase Lys-C, which generates two proteolytic products from the carboxyl terminus of Ets-1 (Fig. 5A). The $\Delta$ N246 fragment is produced first by cleavage carboxy-terminal of lysine 245 and includes all of the calcium-dependent phosphorylation sites. This fragment is then cleaved within the inhibitory module to yield $\Delta$ N302. The inhibitory module of the L429A mutant displays dramatically enhanced production of $\Delta \mathrm{N} 302$ by Lys-C (data not shown). Thus, this Lys-C sensitivity is similar to the trypsin sensitivity in helix HI-1, which has been used previously to gauge the conformation of the inhibitory module (Fig. 3; Petersen et al. 1995; Jonsen et al. 1996).

The digestion of $\Delta \mathrm{N} 246$ to yield $\Delta \mathrm{N} 302$ provides an indicator of the stability of the inhibitory module. To test the effect of phosphorylation on the stability of the inhibitory module, the Lys-C sensitivity of Ets-1 was analyzed after mock treatment or phosphorylation by CaMKII (Fig. 5B,C). The amount of $\Delta$ N246 produced at each concentration of Lys-C was approximately equal for unmodified or phosphorylated Ets-1. However, the ratio of $\Delta$ N302 to $\Delta$ N246 was significantly higher in mocktreated Ets- 1 than in phosphorylated Ets-1. Thus, phosphorylated $\Delta \mathrm{N} 246$ is less sensitive to Lys-C at residues near helix HI-1. These findings demonstrate that the inhibitory module is shifted toward the folded conformation by phosphorylation and strongly indicate that phosphorylation inhibits Ets-1 DNA binding by stabilizing the inhibitory module.

\section{Discussion}

\section{Model for phosphorylation-dependent inhibition} of Ets-1 DNA binding

Our studies of Ets-1 DNA binding have established a link between the phenomena of autoinhibition and phosphorylation-dependent regulation. The Ets-1 inhibitory module is modeled as a four-helix bundle created by packing of three inhibitory $\alpha$-helices with helix $\mathrm{H} 1$ of the ETS domain (Skalicky et al. 1996; Fig. 1). Ets-1 DNA binding is accompanied by a conformational change from the folded to the unfolded state. Specifically, helix HI-1 unfolds on DNA binding (Petersen et al. 1995; Jonsen et al. 1996). The relatively low DNA-binding affinity of Ets-1 is proposed to be due to this required conformational change that couples the stability of the inhibitory module to DNA binding. These findings lead to a model of Ets-1 in which the inhibitory module exists in equi- 


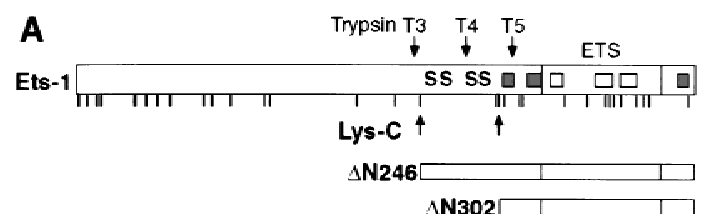

B Mock-treated
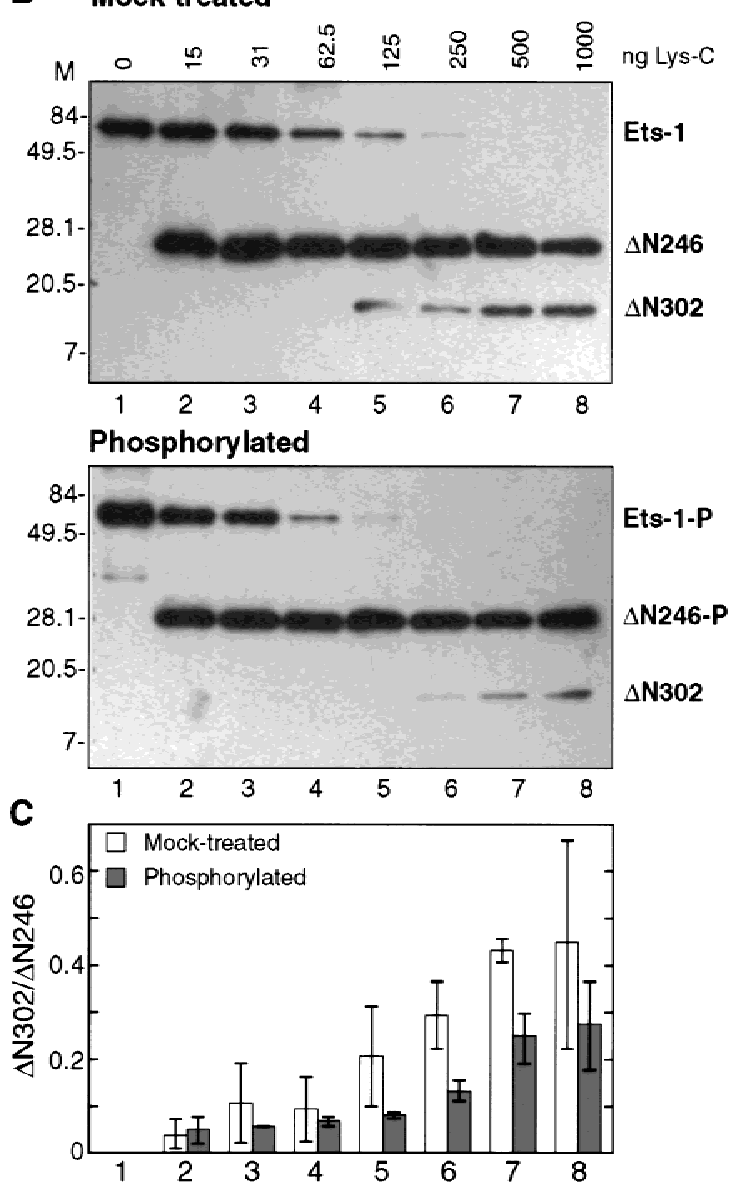

Figure 5. CaMKII phosphorylation stabilizes the Ets-1 inhibitory module. (A) Schematic of full-length Ets-1 and carboxyterminal proteolytic fragments from endoproteinase Lys-C digestion. Potential Lys-C cleavage sites are indicated by vertical lines (see Fig. 3A for sequence). Previously characterized trypsin cleavage sites are labeled as in Fig. 3C. Calcium-dependent phosphorylation sites are indicated by S. $\alpha$-Helices of the ETS domain and inhibitory module are indicated by rectangles. $(B)$ Western analysis of Lys-C partial proteolysis. Mock-treated (top) or phosphorylated (bottom) Ets-1 was digested with indicated amounts of endoproteinase Lys-C and analyzed by SDSPAGE and Western blotting with antiserum specific to the Ets-1 carboxyl terminus. $(C)$ Quantitation of Western blots. The ratio of $\Delta \mathrm{N} 302 / \Delta \mathrm{N} 246$ was obtained by densitometry of Western blots from $B$. Data show mean ( \pm S.D.) of two experiments.

librium between folded and unfolded states. Three lines of evidence in this report suggest that phosphorylation inhibits Ets-1 DNA binding by shifting this equilibrium toward the folded state (Fig. 6). First, phosphorylation of serines $251,257,282$, and 285 synergistically inhibits
Ets-1 DNA binding, suggesting the involvement of structural elements. Next, Ets-1 mutants that display constitutively disrupted inhibitory modules are resistant to inhibition by phosphorylation, indicating that the folding of the inhibitory module is critical for this inhibition. Finally, the protease experiments indicate that phosphorylation reduces cleavage within the inhibitory module, consistent with a shift of the conformational equilibrium towards the folded state. Together, these three observations support the model that phosphorylation inhibits Ets-1 DNA binding by stabilizing the inhibitory module.

How might phosphorylation stabilize the inhibitory module? We hypothesize that negatively charged phosphate groups promote electrostatic interactions between the phosphorylated region and the inhibitory module (Fig. 6). The calcium-dependent phosphorylation sites are found in primary sequence environments punctuated by regularly spaced acidic residues (Fig. 1C). Phosphorylation of the four serines would increase the local negative charge substantially, facilitating ion-pairing interactions with positively charged residues of the inhibitory module. Inhibitory helix HI-1 is within a 21-residue segment of Ets-1 that contains eight basic amino acids (Fig. $3 \mathrm{~A})$. Interactions between these basic residues and the phosphorylated serines could reduce local unfolding, thus stabilizing the entire inhibitory module. Consistent with this proposal, substitution of the four phosphoacceptor serines with glutamic acid partially mimics the effects of phosphorylation (data not shown).

The synergistic inhibitory effects of the four phosphoserines suggest that structural elements may exist within the phosphorylated region. Arginine 263, a potential trypsin site between the pairs of phosphoacceptor residues, is not cleaved in proteolysis experiments (Jonsen et al. 1996), suggesting that residues in this region may be constrained. Secondary or tertiary structure could cluster the pairs of phosphorylated serines, enhancing electrostatic interactions with the positively charged surface of the inhibitory module. Experiments are underway to test the predictions of this model.

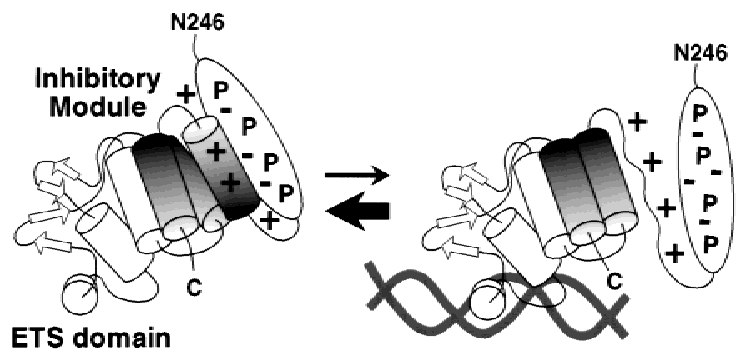

Figure 6. Model of phosphorylation-dependent inhibition of Ets-1 DNA binding. Electrostatic interactions between phosphoserines $(\mathrm{P})$ and basic residues of the inhibitory module stabilize the inhibitory conformation, shifting the equilibrium toward the folded state. DNA binding is repressed by the higher energetic cost of the conformational change that accompanies DNA binding. 


\section{A new biological role for autoinhibition}

The finding that phosphorylation enhances Ets-1 autoinhibition provides a new perspective on the role of autoinhibition in a biological setting. Autoinhibition has been viewed as a mechanism to repress protein activity in the absence of biological inputs that counteract the inhibition. By this view, autoinhibitory mechanisms function as simple switches to keep the activity of a protein off until a signal turns the activity on. For example, cooperative DNA binding between heterologous transcription factors can disrupt autoinhibition of DNA binding, allowing one or both factors to bind with high affinity in the presence of the partner. Examples of this phenomenon include cooperative binding partnerships between a1 and $\alpha 2$ (Stark et al. 1999), PU.1 and Pip (Brass et al. 1996), Elk-1 or Sap-1 and SRF (Dalton and Treisman 1992; Ling et al. 1997), and others. Phosphorylation also has been described as a biological input that can counteract transcription factor autoinhibition. For example, phosphorylation derepresses the DNA-binding activity of p53 (Ko and Prives 1996) and the transcriptional activation capabilities of C/EBP $\beta$ (Kowenz-Leutz et al. 1994) and NF-кB p65 (Zhong et al. 1998). Thus, autoinhibition can restrict transcriptional activities to cellular contexts in which an appropriate partner protein or signal counteracts the repression. Our results expand this traditional view of autoinhibition by demonstrating that an inhibitory module can provide a structural switch to repress activity in response to a signaling event.

In concert with other studies of Ets-1 DNA binding and autoinhibition, our results suggest that the Ets-1 inhibitory module acts as a rheostat that regulates DNA binding in response to biological signals. Our data demonstrate that calcium-dependent phosphorylation uses the inhibitory module to repress Ets-1 DNA binding. On the other hand, Ets-1 binds DNA cooperatively with several binding partners that could counteract autoinhibition. Ets-1 partners include NF-кB (Bassuk et al. 1997; Dickinson et al. 1999), Jun/Fos (Logan et al. 1996), USF and TFE3 (Sieweke et al. 1998; Tian et al. 1999), and CBF 2 (Wotton et al. 1994; Kim et al. 1999; Goetz et al. 2000; Gu et al. 2000). Whereas the mechanism of cooperative binding with most of these proteins has not been characterized, in the case of $\mathrm{CBF} \alpha 2$, cooperative binding has been shown to occur via CBF-mediated disruption of Ets-1 autoinhibition (Goetz et al. 2000; Gu et al. 2000). Thus, the Ets-1 inhibitory module maintains the DNAbinding activity in a partially repressed state, allowing the binding to be enhanced by protein partners or repressed further by calcium-dependent phosphorylation in response to cellular activation.

\section{Biological roles for calcium-dependent regulation of Ets-1 DNA binding}

Functional data indicate that Ets-1 regulates genes important for lymphocyte biology. Gene inactivation studies in mice have demonstrated that Ets-1 is required for the development of natural killer cells and for normal differentiation, homeostasis, and activation of $\mathrm{T}$ and $\mathrm{B}$ lymphocytes (Bories et al. 1995; Muthusamy et al. 1995; Barton et al. 1998). Although the critical target genes regulated by Ets-1 are not known, these phenotypes support a role for Ets-1 in lymphocyte activation. Endogenous Ets-1 is phosphorylated by calcium signals during lymphocyte activation (Pognonec et al. 1988; Fisher et al. 1991), suggesting that the phenomenon regulates activation-dependent transcriptional responses. The results presented here confirm that these calcium signals inhibit Ets-1 DNA binding dramatically. These observations are compatible with two distinct models for the role of calcium-signaling in Ets-1 function.

First, the calcium-dependent inhibition of Ets-1 DNA binding could be part of a general mechanism to remove Ets-1 function from the cell during activation. Expression of ets-1 is down-regulated after cellular activation (Bhat et al. 1990), suggesting that Ets-1 may need to be eliminated from the activated cell. Thus, calcium-dependent phosphorylation could be a dominant, rapid mechanism to inactivate Ets-1 DNA binding as a part of this clearance mechanism. In this model, Ets-1 function would be restricted to resting lymphocytes.

Our new mechanistic insights suggest an alternative role for calcium signaling in the regulation of Ets-1. As discussed above, the inhibitory module mediates both negative regulation of DNA binding in response to phosphorylation and cooperative DNA binding with protein partners. We propose that certain protein partners are able to override the inhibitory effects of phosphorylation. In this model, cellular activation and phosphorylation would specifically direct Ets-1 to target sites with partner proteins that could overcome the phosphorylation-induced inhibition of DNA binding. In support of this model, Ets-1 can mediate activation-dependent transcriptional responses from certain promoter elements in transient overexpression assays in association with other DNA binding proteins (Lambert et al. 1997; Thomas et al. 1997; Blumenthal et al. 1999). The ets-1 expression data could be accommodated in this model if such transcriptional events were restricted to a relatively short interval after cellular activation but prior to elimination of Ets-1. The mechanistic modeling from this study will guide future biological and biochemical investigation of these proposed models.

In summary, our results highlight the critical role of the Ets-1 inhibitory module as an effector of both positive and negative DNA-binding regulation. Autoinhibition is a common feature of kinases, phosphatases, and transcription factors (Soderling 1990; Kemp et al. 1996; Graves et al. 1998). These classes of proteins are the key players in the chain of signaling events that control cell growth, differentiation, and homeostasis. This essential role necessitates tight control of these protein activities as well as mechanisms to modulate the activities in response to appropriate stimuli. Our results demonstrate that autoinhibitory mechanisms can provide this control by acting as structural switches that integrate various biological inputs to generate appropriate responses. 


\section{Materials and methods}

Site-directed mutagenesis and construction of bacterial expression constructs

Mutant forms of murine Ets-1 were generated by site-directed mutagenesis. Primers for phosphorylation site mutants include serines 251 and 257 to alanine: 5'-CTATCGTAGGCCTCTACGCTCTCAAACGCGTCCTGGCCCCCG-3'; serines 282 and 285 to alanine: 5'-CGTAGTCGAAGGCGTCATATGCGGGGACCCGCTGCAGGC-3'. L429A substitution was generated using the primer 5'-CCAGCATGGCGTGCGCCTCTTCAGGG-3'. Mutations were placed into the context of full-length ets- 1 in the pAED-4 expression vector, a derivative of pET3 that bears a high-copy origin of replication (Doering 1992). FlagEts-1 was generated by cloning a FLAG/HMK (Blanar and Rutter 1992) cassette into the NdeI site of the pET3a-Ets-1 construct (Nye et al. 1992). The Flag-L429A and Flag-Y307P mutants were generated with the following primers L429A, 5'CAGCATGGCGTGCGCCTCTTCAGGGGTG-3' and Y307P, 5'-CACCTTCAAGGACCCTGTGCGTGACCGTGC-3'.

\section{Protein expression and purification}

All mutant Ets-1 proteins were expressed in Escherichia coli BL21 (DE3). In the case of wild-type Ets-1, a previously described strain bearing pET3 with a full-length open reading frame of murine Ets- 1 and the pLysS plasmid was available (Nye et al. 1992). Cultures $(500 \mathrm{ml})$ were grown at $37^{\circ} \mathrm{C}$ in Luria broth and protein expression was induced at mid-log phase for $2 \mathrm{hr}$ by addition of $1 \mathrm{~mm}$ IPTG. Harvested cells were resuspended in 25 $\mathrm{ml}$ of lysis buffer (25 mM Tris-Cl at $\mathrm{pH} 7.9,0.1 \mathrm{M}$ EDTA, $1 \mathrm{M}$ $\mathrm{KCl}$ ) with $1 \mathrm{~mm}$ phenylmethylsulfonyl fluoride (PMSF) and 1 mM dithiothreitol (DTT) and lysed by sonication (Heat Systems, Inc). The insoluble fraction was collected by centrifugation at $27,000 \mathrm{~g}$ for $15 \mathrm{~min}$. To wash the pellet, sonication and centrifugation were repeated. The insoluble pellet was solubilized by sonication in $25 \mathrm{ml}$ of $10 \mathrm{~mm}$ Tris-Cl (pH 7.6), $750 \mathrm{~mm} \mathrm{NaCl}, 5$ M urea, 0.1\% (vol/vol) Triton X-100, $1 \mathrm{~mm} \mathrm{DTT,} \mathrm{and} 1 \mathrm{~mm}$ PMSF, then centrifuged at $27,000 \mathrm{~g}$ for $15 \mathrm{~min}$ at $4^{\circ} \mathrm{C}$. The supernatant was loaded on a 5-ml DEAE-cellulose column (Pierce) at $4^{\circ} \mathrm{C}$. The flowthrough fraction was subjected to dialysis at $4^{\circ} \mathrm{C}$, two times for $2 \mathrm{hr}$ each against 10 volumes of TGEK I0 $_{1}(25$ mM Tris-Cl at pH 7.9, 10\% glycerol, 0.1 mM EDTA, $50 \mathrm{~mm} \mathrm{KCl)}$ with $1 \mathrm{~mm}$ DTT and $0.2 \mathrm{~mm}$ PMSF. After dialysis, soluble protein was loaded onto a 26/10 Hi Load S-Sepharose column (Pharmacia) in TGEK with $1 \mathrm{~mm}$ DTT at $4^{\circ} \mathrm{C}$ and eluted with a linear gradient of $\mathrm{KCl}$ from 50 to $500 \mathrm{~mm}$ over five column volumes. All Ets-1 species eluted between $\sim 200$ and $300 \mathrm{~mm}$ $\mathrm{KCl}$. Protein aliquots were snap frozen and stored at $-80^{\circ} \mathrm{C}$.

Purity of Ets- 1 species was estimated to be $>90 \%$ by Coomassie brilliant blue staining of SDS-polyacrylamide gels. Protein concentrations were determined by spectrophotometry after denaturing in $6 \mathrm{M}$ guanidine- $\mathrm{HCl}$ (Pierce), using extinction coefficients calculated based on the method of Gill and von Hippel (1989). The following extinction coefficients were used: Ets-1 wild-type, L429A, 4S-A, S251A;S257A, and S282A;S285A-81200/(M $\times \mathrm{cm})$ at $278 \mathrm{~nm}$; Flag-Ets-1, FlagL429A - 80650/M $\times \mathrm{cm}$ ) at $280 \mathrm{~nm}$; Flag-Y307P_79370 $\mathrm{M} \mathrm{x} \mathrm{cm}$ at $280 \mathrm{~nm}$. The concentration of the Ets-1 4S-A protein was corrected to reflect active protein concentration as determined experimentally by DNA titration (Jonsen et al. 1996). The active concentrations of other serine mutant Ets-1 proteins were not determined because, unlike 4 S-A, the binding affinities were within the range of $2 \times 10^{-10}$ to $4 \times 10^{-10} \mathrm{M}$ expected from previous analyses in which preparations were determined to be $100 \%$ active (Jonsen et al. 1996).
Kinase assays and quantitation of Ets-1 phosphorylation

Nuclear extract was prepared from the murine T cell hybridoma Hd11.2 (Meikle et al. 1992, a generous gift of Dr. Ray Daynes, University of Utah) as described previously (Gunther and Graves 1994) except that buffer A (lysis buffer) was supplemented with $1 \mathrm{~mm}$ EGTA. Total protein concentration of nuclear extract preparations ranged from 4 to $6 \mathrm{mg} / \mathrm{ml}$ as determined by Bradford assay (Bio-Rad). Nuclear extract kinase assays were performed at $30^{\circ} \mathrm{C}$ for $30 \mathrm{~min}$ in kinase buffer $(30 \mathrm{~mm}$ HEPES at pH 7.5, $7 \mathrm{mM} \mathrm{MgCl}_{2}, 100 \mu \mathrm{MaCl}_{2}$, and $1 \mathrm{~mm} \mathrm{DTT)}$ with $1 \mathrm{mg} / \mathrm{ml}$ nuclear extract protein, $1.25 \mu \mathrm{M}$ Ets-1 and $1 \mathrm{~mm}$ unlabeled or $\left[\gamma^{32} \mathrm{P}\right]$ ATP $(\sim 150 \mathrm{mCi} / \mathrm{mmole})$. Products of reactions with unlabeled ATP were diluted into DNA-binding buffer for EMSA analysis. Reactions with $\left[\gamma^{-32} \mathrm{P}\right] \mathrm{ATP}$ were stopped by adding Laemmli SDS-PAGE sample buffer and heating to $95^{\circ} \mathrm{C}$ for $5 \mathrm{~min}$, then separated by SDS-PAGE. Gels were stained with Coomassie brilliant blue, dried, and analyzed by PhosphorImager with Image Quant (v. 1.1, Molecular Dynamics).

CaMKII $\alpha$, purified from a baculovirus expression system, was generously provided by Dr. Thomas Soderling (Oregon Health Sciences University, Portland). CaMKII kinase assays were performed at $30^{\circ} \mathrm{C}$ for $30 \mathrm{~min}$ with $50 \mathrm{~mm}$ HEPES (pH 7.5), $10 \mathrm{~mm}$ magnesium acetate, $0.5 \mathrm{~mm} \mathrm{CaCl}_{2}, 2 \mathrm{~mm}$ DTT, $1 \mu \mathrm{M}$ calmodulin (Calbiochem), $2 \mu \mathrm{M}$ Ets-1, and $100 \mathrm{~nm}$ CaMKII. Unlabeled or $\left[\gamma-{ }^{32} \mathrm{P}\right]$ ATP was added at $0.4 \mathrm{~mm}$ to appropriate reactions. CaMKII was diluted appropriately in $50 \mathrm{~mm}$ HEPES (pH 7.5), $10 \%$ ethylene glycol, $2 \mathrm{mg} / \mathrm{ml}$ bovine serum albumin (BSA) before adding to reactions.

The apparent stoichiometry of Ets-1 phosphorylation (moles of phosphate per mole of Ets-1) was estimated from kinase reactions that included $\left[\gamma_{-}{ }^{32} \mathrm{P}\right] \mathrm{ATP}$ as follows. Precise quantities of $\left[\gamma^{32} \mathrm{P}\right]$ ATP $(10-500$ pmoles) were spotted on filter paper. Phosphorimaging of these known quantities of isotope concurrently with SDS gels containing known quantities of phosphorylated Ets-1 provided data to convert the signal from Ets-1 gel bands into moles of phosphate per mole of Ets-1.

Repurification and phosphatase treatment of phosphorylated Flag-Ets-1 proteins

Kinase assays were performed as described above with $2 \mathrm{mg} / \mathrm{ml}$ nuclear extract protein, $2.5 \mu \mathrm{M}$ Flag-Ets-1 or Flag-L429A, and 1 mM unlabeled ATP in appropriate reactions. Flag-tagged proteins were repurified with anti-Flag M2-Agarose (Sigma) and eluted with Flag peptide (Sigma) at $500 \mu \mathrm{g} / \mathrm{ml}$ in $25 \mathrm{~mm}$ Tris-Cl (pH 7.9), 0.1 mm EDTA, 50 mm KCl, 1 mm DTT. Concentrations of repurified proteins were determined by densitometry of Coomassie-blue-stained SDS-polyacrylamide gels with a standard curve prepared from known amounts of pure Flag-Ets-1. Phosphatase experiments were performed with phosphorylated, repurified Flag-Ets-1, or Flag-L429A. Phosphorylated proteins were incubated with 10 units of calf intestinal phosphatase (New England Biolabs) at $30^{\circ} \mathrm{C}$ for $30 \mathrm{~min}$, then the reaction was stopped by addition of phosphatase inhibitors $(50 \mathrm{~mm} \mathrm{NaF}, 20$ $\mathrm{mM} \beta$-glycerol phosphatase, $2 \mathrm{mM} \mathrm{Na}_{3} \mathrm{VO}_{4}$, and $5 \mathrm{mM} \mathrm{Na}_{4} \mathrm{P}_{2} \mathrm{O}_{7}$ ). An equivalent amount of control protein was incubated at $4{ }^{\circ} \mathrm{C}$ with phosphatase inhibitors. Reaction mixtures were stored at $4^{\circ} \mathrm{C}$ until dilution into binding buffer for DNA-binding assays.

\section{DNA-binding assays}

$K_{d}$ s were measured by EMSA with the high-affinity ets-binding site duplex SC1 (Nye et al. 1992) as described previously (Jonsen et al. 1996). In brief, binding reaction mixtures were prepared on 
ice in $20 \mu$ l with $25 \mathrm{~mm}$ Tris-Cl (pH 7.9), 10\% glycerol, $0.1 \mathrm{~mm}$ EDTA, $60 \mathrm{~mm} \mathrm{KCl}, 6 \mathrm{~mm} \mathrm{MgCl} 2,0.2 \mathrm{mg} / \mathrm{ml} \mathrm{BSA}, 10 \mathrm{~mm}$ DTT, and $50 \mathrm{ng}$ of poly[d(I-C)]. EMSA was performed at $4{ }^{\circ} \mathrm{C}$ on $5 \%$ native polyacrylamide gels in $0.5 \times$ TBE buffer. $K_{d}$ s were determined by plotting the fraction of bound DNA ([DP]/[D $\left.\left.\mathrm{D}_{t}\right]\right)$ versus the concentration of free protein $([\mathrm{P}])$ and fitting the mean data points to the rearranged mass action equation $[D P] /\left[D_{t}\right]=1 /$ $\left(1+\left(K_{d} /[P]\right)\right)$ using nonlinear least-squares analyses (KaleidaGraph, v. 3.0, Synergy Software) (Jonsen et al. 1996). The total concentration of DNA $\left(\left[D_{t}\right]\right)$ was at least 10 -fold below the expected $K_{d}$ of the Ets-1 species, allowing the assumption that free protein concentration was approximately equal to total protein concentration. The fraction of bound DNA was calculated from PhosphorImager analysis of the free DNA signal as this is the most accurately measured parameter in EMSA (Carey 1991). The fraction of bound DNA at each Ets-1 concentration was calculated from the fraction of free DNA, $[D P] /\left[D_{t}\right]=1-([D] /$ $\left.\left[D_{t}\right]\right)$. Data points are mean values from 3 experiments except where noted. Error bars represent standard deviation of the mean for each point. Fold inhibition reported in Fig. 4D and Table 1 was calculated as the ratio $K_{d}$ phosphorylated $/ K_{d}$ mock treated.

The phosphorylation-dependent inhibition measured for nonrepurified, extract-treated Ets-1 was only $\sim 17$-fold (Table 1), owing to the fact that binding curves were generated by measuring the free DNA fraction. Upon inhibition of Ets-1 DNA binding, the background DNA-binding activities in nuclear extract contributed significantly to the disappearance of the free DNA signal (data not shown). Thus, the presence of nuclear extract prohibited accurate measurement of binding constants for phosphorylated wild-type Ets-1. DNA-binding experiments reported for mutant Ets-1 proteins were performed without repurification because, unlike wild-type Ets-1, the binding activities of mutant proteins were above the background of the nuclear extract regardless of their phosphorylation state (e.g., Fig. 4B).

L429A and Y307P display 5- to 10-fold higher affinity than wild-type Ets-1 only in the absence of $\mathrm{MgCl}_{2}$ (data not shown). Therefore, in experiments with these proteins, $\mathrm{MgCl}_{2}$ was omitted from DNA-binding buffer and EDTA was added to a final concentration of $5 \mathrm{~mm}$. This change had very little effect $(2 \times)$ on the binding affinity of wild-type Ets-1 (data not shown). Nevertheless, DNA-binding experiments of wild-type Ets-1 treated with CaMKII or Flag-Ets-1 repurified from nuclear extracts were performed without $\mathrm{MgCl}_{2}$ to allow direct comparison to L429A. Flag-L429A, Flag-Y307P, and wild-type Ets-1 experienced a loss of DNA-binding activity during incubation at $30^{\circ} \mathrm{C}$ (cf. Figs. 3B and 4C). Our experimental design controlled for this phenomenon by directly comparing the effect of phosphorylation only to mock-treated controls.

\section{Proteolysis assays}

For Lys-C experiments, Ets-1 was mock-treated or phosphorylated by CaMKII as described above except that $50-\mu 1$ reactions contained Ets-1 and CaMKII concentrations of $10 \mu \mathrm{M}$ and 250 $\mathrm{nM}$, respectively, and CaMKII was diluted in $50 \mathrm{~mm}$ HEPES $\mathrm{pH}$ $7.5)$ and $10 \%$ ethylene glycol without BSA. In control reactions, these conditions resulted in full phosphorylation of Ets- 1 in $<30$ min at $30^{\circ} \mathrm{C}$ (data not shown). After $30 \mathrm{~min}$ at $30^{\circ} \mathrm{C}$, reactions were stopped by addition of EDTA to $20 \mathrm{~mm}$ final concentration. Sequencing grade endoproteinase Lys-C (Promega) was diluted in $25 \mathrm{~mm}$ sodium phosphate (pH 7.7), $1 \mathrm{~mm}$ EDTA. Aliquots of kinase reaction mix $(5 \mu 1, \sim 2.5 \mu$ g of Ets-1) were added to $5 \mu \mathrm{l}$ appropriately diluted Lys-C and incubated $1 \mathrm{hr}$ at $30^{\circ} \mathrm{C}$. Reactions were stopped by addition of SDS-PAGE sample buffer and $5 \mathrm{~min}$ incubation at $95^{\circ} \mathrm{C}$. Approximately $200 \mathrm{ng}$ of Ets- 1 digestion products were resolved by $15 \%$ SDS-PAGE and transferred to PVDF membrane (Bio-Rad) in $25 \mathrm{~mm}$ Tris (pH 8.3), 192 mM glycine, $20 \%$ methanol, $0.1 \%$ SDS. Western analysis used rabbit polyclonal antiserum directed against the carboxyl terminus of Ets-1 (Gunther and Graves 1994) and ECL Plus detection system (Amersham). Quantitation was performed by autoradiography and densitometry using Image Quant (v. 1.1 Molecular Dynamics).

Trypsin digestions were performed in $20 \mu \mathrm{l}$ of buffer $(25 \mathrm{~mm}$ Tris at $\mathrm{pH} 7.9,10 \mathrm{~mm} \mathrm{CaCl}_{2}, 1 \mathrm{~mm}$ DTT) with $5.5 \mu \mathrm{M}$ Flag-Ets1, Flag-L429A, or Flag-Y307P and 0, 20, or 200 ng of trypsin (Sigma). Reaction mixtures were incubated $2 \mathrm{~min}$ at $25^{\circ} \mathrm{C}$, then stopped as described above. Products were separated by $15 \%$ SDS-PAGE and visualized by staining with Coomassie blue. Amino termini of trypsin and Lys-C digestion products were determined by Edman sequencing on an ABI 477A protein sequencer (Applied Biosystems).

\section{Acknowledgments}

We thank Nathan Heaps and Drs. Thomas Soderling and Raymond Daynes for providing reagents used in these studies. We are grateful to Dr. Brad Cairns and members of the Graves laboratory for helpful suggestions. This work was supported by the National Institutes of Health (GM-38663 to B.J.G., predoctoral fellowship HD-07491 to D.O.C., and CA-24014 to core facilities of the Huntsman Cancer Institute). Support from the Center for Excellence in Molecular Hematology DK49219 is also acknowledged.

The publication costs of this article were defrayed in part by payment of page charges. This article must therefore be hereby marked "advertisement" in accordance with 18 USC section 1734 solely to indicate this fact.

\section{References}

Barton, K., N. Muthusamy, C. Fischer, C.-N. Ting, T. Walunas, L. Lanier, and J. Leiden. 1998. The Ets-1 transcription factor is required for the development of natural killer cells in mice. Immunity 9: 555-563.

Bassuk, A.G., R.T. Anandappa, and J.M. Leiden. 1997. Physical interactions between Ets and NF-kappaB/NFAT proteins play an important role in their cooperative activation of the human immunodeficiency virus enhancer in T cells. J. Virol. 71: 3563-3573.

Batchelor, A., D. Piper, F. Charles de la Brousse, S. Mcknight, and C. Wolberger. 1998. The structure of GABP $\alpha / \beta$ : An ETS domain-ankryin repeat heterodimer bound to DNA. Science 279: 1037-1041.

Bhat, N.K., C.B. Thompson, T. Lindsten, C.H. June, S. Fujiwara, S. Koizumi, R.J. Fisher, and T.S. Papas. 1990. Reciprocal expression of human ETS1 and ETS2 genes during T-cell activation: Regulatory role for the protooncogene ETS1. Proc. Natl. Acad. Sci. 87: 3723-3727.

Blanar, M.A. and W.J. Rutter. 1992. Interaction cloning: Identification of a helix-loop-helix zipper protein that interacts with c-Fos. Science 256: 1014-1018.

Blumenthal, S.G., G. Aichele, T. Wirth, A.P. Czernilofsky, A. Nordheim, and J. Dittmer. 1999. Regulation of the human interleukin-5 promoter by Ets transcription factors. Ets 1 and Ets2, but not Elf-1, cooperate with GATA3 and HTLV-I Tax1. J. Biol. Chem. 274: 12910-12916.

Bories, J.-C., D.M. Willerford, D. Grevin, L. Davidson, A. Camus, P. Martin, D. Stehelin, and F.W. Alt. 1995. Increased 
T-cell apoptosis and terminal B-cell differentiation induced by inactivation of the Ets-1 proto-oncogene. Nature 377: 635-638.

Brass, A.L., E. Kehrli, C.F. Eisenbeis, U. Storb, and H. Singh. 1996. Pip, a lymphoid-restricted IRF, contains a regulatory domain that is important for autoinhibition and ternary complex formation with the ets factor PU.1. Genes \& Dev. 10: $2335-2347$.

Carey, J. 1991. Gel retardation. Methods Enzymol. 208: 103117.

Dalton, S. and R. Treisman. 1992. Characterization of SAP-1, a protein recruited by serum response factor to the c-fos serum response element. Cell 68: 597-612.

Dickinson, L.A., J.W. Trauger, E.E. Baird, P.B. Dervan, B.J. Graves, and J.M. Gottesfeld. 1999. Inhibition of Ets-1 DNA binding and ternary complex formation between Ets-1, NF$\kappa \mathrm{B}$ and DNA by a designed DNA-binding ligand. I. Biol. Chem. 274: 12765-12773.

Doering, D.S. 1992. "Functional and structural studies of a small F-actin binding domain." Ph.D. Thesis, Massachusetts Institute of Technology, Cambridge, MA.

Donaldson, L.W., J.M. Petersen, B.J. Graves, and L.P. McIntosh. 1996. Solution structure of the ETS domain from murine Ets-1: A winged helix-turn-helix DNA binding motif. EMBO J. 15: 125-134.

Finco, T.S., J.K. Westwick, J.L. Norris, A.A. Beg, C.J. Der, and A.S. Baldwin, Jr. 1997. Oncogenic Ha-Ras-induced signaling activates NF- $\mathrm{KB}$ transcriptional activity, which is required for cellular transformation. J. Biol. Chem. 272: 2411324116.

Fisher, C.L., J. Ghysdael, and J.C. Cambier. 1991. Ligation of membrane Ig leads to calcium-mediated phosphorylation of the proto-oncogene product, Ets-1. J. Immunol. 146: 17431749.

Fisher, R.J., M. Favash, J. Casas-Finet, J.W. Erickson, A. Kondoh, S.V. Bladen, C. Fisher, D.K. Watson, and T. Papas. 1994. Real-time DNA binding measurements of the ETS1 recombinant oncoproteins reveal significant kinetic differences between the p42 and p51 isoforms. Protein Sci. 3: 257-266.

Gill, S.C. and P.H. von Hippel. 1989. Calculation of protein extinction coefficients from amino acid sequence data. Anal. Biochem. 182: 319-326.

Goetz, T.L., T.L. Gu, N.A. Speck, and B.J. Graves. 2000. Autoinhibition of Ets-1 is counteracted by DNA binding cooperativity with core-binding factor $\alpha 2$. Mol. Cell. Biol. 20: 8190.

Gonzalez, G.A. and M.R. Montminy. 1989. Cyclic AMP stimulates somatostatin gene transcription by phosphorylation of CREB at serine 133. Cell 59: 675-680.

Graves, B.J. and J.M. Petersen. 1998. Specificity within the ets family of transcription factors. In Advances in cancer research (ed. G.V. Woude and G. Klein), pp. 1-55. Academic Press, San Diego, CA.

Graves, B.J., D.O. Cowley, T.L. Goetz, J.M. Petersen, M.D. Jonsen, and M.E. Gillespie. 1998. Autoinhibition as a transcriptional regulatory mechanism. Cold Spring Harbor Symp. Quant. Biol. 63: 621-629.

Gu, T.L., T.L. Goetz, B.J. Graves, and N.A. Speck. 2000. Autoinhibition and partner proteins, core-binding factor $\beta(\mathrm{CBF} \beta)$ and Ets-1, modulate DNA binding by CBF 22 (AML1). Mol. Cell. Biol. 20: 91-103.

Gunther, C.V. and B.J. Graves. 1994. Identification of ETS domain proteins in murine $\mathrm{T}$ lymphocytes that interact with the Moloney murine leukemia virus enhancer. Mol. Cell. Biol. 14: 7569-7580.

Hagman, J. and R. Grosschedl. 1992. An inhibitory carboxyl terminal domain in Ets-1 and Ets-2 mediates differential binding of ETS family factors to promoter sequences of the mb-1 gene. Proc. Natl. Acad. Sci. 89: 8889-8893.

Jonsen, M. 1999. "Auto-inhibition of DNA binding in the transcription factor Ets-1: A mechanistic and structural study." Ph.D. Thesis, University of Utah, Salt Lake City, UT.

Jonsen, M.D., J.M. Petersen, Q. Xu, and B.J. Graves. 1996. Characterization of the cooperative function of inhibitory sequences of Ets-1. Mol. Cell. Biol. 16: 2065-2073.

Kemp, B.E., J.A. Barden, B. Kobe, C. House, and M.W. Parker. 1996. Intrasteric regulation of calmodulin-dependent protein kinases. Adv. Pharmacol. 36: 221-249.

Kim, W.-Y., M. Sieweke, D. Ogawa, H.-J. Wee, U. Englemeier, T. Graf, and Y. Ito. 1999. Mutual activation of Ets-1 and AML1 DNA binding by direct interaction of their autoinhibitory domains. EMBO J. 18: 1609-1620.

Ko, L.J. and C. Prives. 1996. p53: Puzzle and paradigm. Genes \& Dev. 10: 1054-1072.

Kodandapani, R., F. Pio, C.-Z. Ni, G. Piccialli, M. Klemsz, S. McKercher, R.A. Maki, and K.R. Ely. 1996. A new pattern for helix-turn-helix recognition revealed by the PU.1 ETS-domain-DNA complex. Nature 380: 456-460.

Kowenz-Leutz, E., G. Twamley, S. Ansieau, and A. Leutz. 1994. Novel mechanism of C/EBP (NF-M) transcriptional control: Activation through derepression. Genes \& Dev. 8: 27812791.

Lambert, P.F., M.J. Ludford-Menting, N.J. Deacon, I. Kola, and R.R. Doherty. 1997. The nfkbl promoter is controlled by proteins of the Ets family. Mol. Biol. Cell 8: 313-323.

Lim, F., N. Kraut, J. Frampton, and T. Graf. 1992. DNA binding by c-Ets-1, but not v-Ets, is repressed by an intramolecular mechanism. EMBO J. 11: 643-652.

Ling, Y., J.H. Lakey, C.E. Roberts, and A.D. Sharrocks. 1997. Molecular characterization of the B-box protein-protein interaction motif of the ETS-domain transcription factor Elk-1. EMBO J. 16: 2431-2440.

Logan, S.K., M.J. Garabedian, C.E. Campbell, and Z. Werb. 1996. Synergistic transcriptional activation of the tissue inhibitor of metaloproteinases-1 promoter via functional interaction of AP-1 and Ets-1 transcription factors. J. Biol. Chem. 271: 774-776.

Marais, R., J. Wynne, and R. Treisman. 1993. The SRF accessory protein Elk-1 contains a growth factor-regulated transcriptional activation domain. Cell 73: 381-393.

Meikle, A.W., R.W. Dorchuck, B.A. Araneo, J.D. Stringham, T.G. Evans, S.L. Spruance, and R.A. Daynes. 1992. The presence of a dehydroepiandrosterone-specific receptor binding complex in murine T cells. J. Steroid Biochem. Mol. Biol. 42: 293-304.

Mo, Y., B. Vaessen, K. Johnston, and R. Marmorstein. 1998. Structures of SAP-1 bound to DNA targets from the E74 and c-fos promoters: Insights into DNA sequence discrimination by Ets proteins. Mol. Cell 2: 201-212.

Montminy, M. 1997. Transcriptional regulation by cyclic AMP. Annu. Rev. Biochem. 66: 807-822.

Muthusamy, N., K. Barton, and J.M. Leiden. 1995. Defective activation and survival of T-cells lacking the Ets- 1 transcription factor. Nature 377: 639-642.

Nye, J.A., J.M. Petersen, C.V. Gunther, M.D. Jonsen, and B.J. Graves. 1992. Interaction of murine Ets-1 with GGA-binding sites establishes the ETS domain as a new DNA-binding motif. Genes \& Dev. 6: 975-990.

Petersen, J.M., J.J. Skalicky, L.W. Donaldson, L.P. McIntosh, T. Alber, and B.J. Graves. 1995. Modulation of transcription factor Ets-1 DNA binding: DNA-induced unfolding of an alpha helix. Science 269: 1866-1869. 
Pognonec, P., K.E. Boulukos, J.C. Gesquiere, D. Stehelin, and J. Ghysdael. 1988. Mitogenic stimulation of thymocytes results in the calcium-dependent phosphorylation of c-ets-1 proteins. EMBO I. 7: 977-983.

Rabault, B. and J. Ghysdael. 1994. Calcium-induced phosphorylation of ETS1 inhibits its specific DNA binding activity. J. Biol. Chem. 269: 28143-28151.

Rao, A., C. Luo, and P.G. Hogan. 1997. Transcription factors of the NFAT family: Regulation and function. Annu. Rev. Immunol. 15: 707-747.

Sieweke, M.H., H. Tekotte, U. Jarosch, and T. Graf. 1998. Cooperative interaction of Ets-1 with USF-1 required for HIV-1 enhancer activity in T cells. EMBO J. 17: 1728-1739.

Skalicky, J.J., L.W. Donaldson, J.M. Petersen, B.J. Graves, and L.P. McIntosh. 1996. Structural coupling of the inhibitory regions flanking the ETS domain of murine Ets-1. Prot. Sci. 5: 296-309.

Soderling, T.R. 1990. Protein kinases: Regulation by auto-inhibitory domains. J. Biol. Chem. 265: 1823-1826.

Stark, M.R., D. Escher, and A.D. Johnson. 1999. A trans-acting peptide activates the yeast al repressor by raising its DNAbinding affinity. EMBO T. 18: 1621-1629.

Thomas, R.S., M.J. Tymms, L.H. McKinlay, M.F. Shannon, A. Seth, and I. Kola. 1997. ETS1, NFкB and AP1 synergistically transactivate the human GM-CSF promoter. Oncogene 14: 2845-2855.

Tian, G., B. Erman, H. Ishii, S.S. Gangopadhyay, and R. Sen. 1999. Transcriptional activation by ETS and leucine zippercontaining basic helix-loop-helix proteins. Mol. Cell. Biol. 4: 2946-2957.

Treisman, R. 1994. Ternary complex factors: Growth regulated transcriptional activators. Curr. Opin. Genet. Dev. 4:96101.

Wasylyk, C., J.-P. Kerckaert, and B. Wasylyk. 1992. A novel modulator domain of Ets transcription factors. Genes \& Dev. 6: 965-974.

Werner, M.H., G.M. Clore, C.L. Fisher, R.J. Fisher, L. Trinh, J. Shiloach, and A.M. Gronenborn. 1997. Correction of the NMR structure of the ETS1/DNA complex. J. Biomol. NMR 10: $317-328$.

Wotton, D., J. Ghysdael, S. Wang, N.A. Speck, and M.J. Owen. 1994. Cooperative binding of Ets-1 and core binding factor to DNA. Mol. Cell. Biol. 14: 840-850.

Yang, B.-S., C.A. Hauser, G. Henkel, M.S. Colman, C. Van Beveren, K.J. Stacey, D.A. Hume, R.A. Maki, and M.C. Ostrowski. 1996. Ras-mediated phosphorylation of a conserved threonine residue enhances the transactivation activities of c-Ets-1 and c-Ets-2. Mol. Cell. Biol. 16: 538-547.

Zhong, H., R.E. Voll, and S. Ghosh. 1998. Phosphorylation of NF-к B p65 by PKA stimulates transcriptional activity by promoting a novel bivalent interaction with the coactivator CBP/p300. Mol. Cell 1: 661-671. 


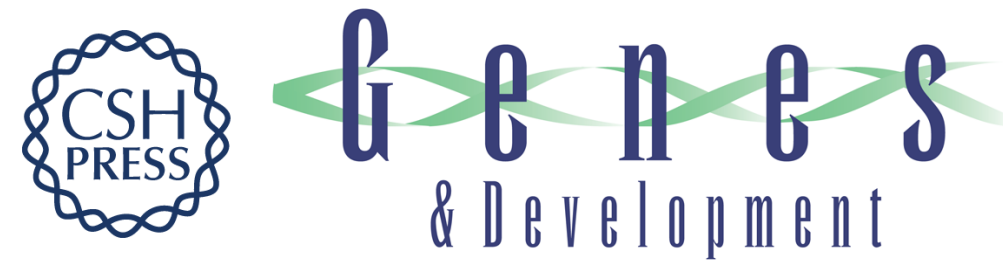

\section{Phosphorylation represses Ets-1 DNA binding by reinforcing autoinhibition}

Dale O. Cowley and Barbara J. Graves

Genes Dev. 2000, 14:

Access the most recent version at doi:10.1101/gad.14.3.366

References This article cites 53 articles, 28 of which can be accessed free at: http://genesdev.cshlp.org/content/14/3/366.full.htmI\#ref-list-1

License

Email Alerting Receive free email alerts when new articles cite this article - sign up in the box at the top Service right corner of the article or click here.

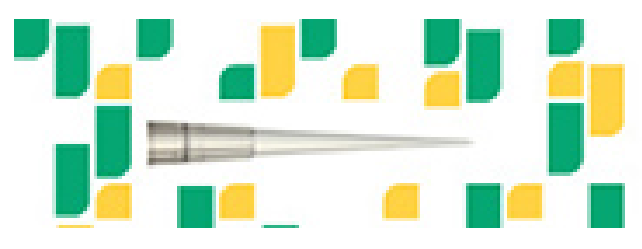

Focused on your science. 